\title{
Utilization of threonine in young pigs fed diets differing in standardized ileal digestible threonine and wheat gluten used as a source of non-essential amino acids
}

\author{
E. Święch ${ }^{1}$ \\ The Kielanowski Institute of Animal Physiology and Nutrition Polish Academy of Sciences \\ 05-110 Jabłonna, Poland
}

KEY WORDS: pigs, threonine, wheat gluten, ileal AA digestibility, nitrogen retention, threonine dehydrogenase activity

Received: $\quad 2$ July 2015

Revised: $\quad 8$ October 2015

Accepted: 25 November 2015
${ }^{1}$ Corresponding author:

e-mail: e.swiech@ifzz.pl

\begin{abstract}
The objective of the study was to determine whether non-essential amino acids (NEAA) in the form of wheat gluten (WG) have a threonine (Thr)-sparing effect in young pigs and to assess the response of hepatic and pancreatic Thr dehydrogenase (TDG) on the increase of Thr and NEAA supply. In Experiment 1, the standardized ileal digestibility (SID) of protein and amino acids (AA) in three low-Thr diets containing $20.4,40.4$, or $60.4 \mathrm{~g}$ of WG protein per kilogram of respective WG20, WG40 and WG60 diets, were determined on male pigs with an initial body weight (BW) of $20 \mathrm{~kg}$. In Experiment 2, the effects of four Thr levels $(5.1,5.7,6.3$ and $6.9 \mathrm{~g}$ SID Thr per $\mathrm{kg}$ ) and three WG levels in diets covering requirements for other SID essential $A A$, on nitrogen retention and TDG activity in the liver and pancreas were studied. The experiment was performed over 20 days on 72 male pigs with an initial BW of $12.5 \mathrm{~kg}$, six pigs per treatment. Nitrogen retention was not affected by either the Thr level or by interaction of Thr and WG levels. It was greater in pigs fed the WG40 and WG60 than WG20 diets. TDG activity in the liver was not influenced by the dietary Thr level and in the pancreas it was the lowest in pigs fed the diet with the lowest Thr concentration, but this was not dose dependent. The WG level influenced TDG activity in both organs differently: in the liver TDG was the greatest in pigs fed the WG60 diet, while in the pancreas it was greater in pigs fed WG20 than WG40, but not WG60. The results do not evidence a sparing effect of NEAA provided by WG on Thr utilization for protein deposition and do not support the hypothesis on TDG activity as a potential unequivocal indicator of the Thr oxidation rate.
\end{abstract}

\section{Introduction}

Threonine (Thr) is an essential amino acid (AA), which is often deficient in cereal-based diets for pigs. The reported requirement of young pigs $(10-25 \mathrm{~kg})$ for Thr varies from 6.3 to $8.7 \mathrm{~g}$ of total Thr per kilogram of diet (Saldana et al., 1994; GfE, 2006; NRC, 2012) and depends mainly on pig genotype, feeding level and diet composition.
In comparison with other AAs, the Thr requirement for maintenance is high since significant amounts of this AA are used by the intestine for synthesis of mucins and are secreted in the form of Thr-rich proteins. Deficiency or excess of Thr may reduce synthesis of intestinal and muscle proteins in weaned pigs (Wang et al., 2007).

Non-essential AAs (NEAA) are also involved in physiological functions of the gut and may improve 
Thr utilization for protein deposition. In an earlier experiment (Święch et al., 2010), NEAA added in the form of wheat gluten (WG) or monosodium glutamate to a low-protein diet with moderate Thr deficiency positively affected nitrogen $(\mathrm{N})$ retention, whereas NEAA in the form of WG also improved the gut structure of young pigs.

Threonine is catabolized mainly through an oxidation pathway by threonine dehydrogenase (TDG). Measurement of Thr oxidation could be helpful in estimation of Thr requirements and provide an estimate for Thr efficiency for body protein deposition in different nutritional situations (Le Floc'h et al., 1996). In pigs, TDG activity was found only in the liver and pancreas, but involvement of these organs in the oxidation of Thr and potential dietary effects on TDG have not been fully established (Le Floc'h et al., 1995, 1997; Le Floc'h and Sève, 2005).

The objective of this study was to determine whether and to what extent the levels of Thr and NEAA affect utilization of Thr for protein deposition in young pigs fed diets balanced for essential AAs (except Thr). WG was used as the source of NEAA as it was assumed that it may have a more extensive sparing effect on Thr metabolism than glutamate. The aim of the study was also to find if activity of TDG as the main Thr catabolic enzyme in the liver and pancreas is influenced by the expected differences in Thr utilization effectiveness and may be considered as a corroborative indicator in studies on Thr requirements in pigs.

\section{Material and methods}

\section{Experimental design}

The experiments were approved by the Local Animal Care Committee. Two experiments were performed. In Experiment 1, the standardized ileal digestibility (SID) of protein and AAs in three low-Thr diets containing three WG contents were determined. The SID values obtained in Experiment 1 were employed to formulate diets covering pig requirements for SID AAs in Experiment 2. In Experiment 2, the effect of supplementing diets containing low SID Thr and three WG contents with graded amounts of Thr were determined using a twofactorial design. Nitrogen retention was determined as the parameter reflecting protein deposition and TDG activity was measured in the liver and pancreas.

\section{Diets}

In Experiment 1, three low-Thr diets containing $20.4,40.4$ or $60.4 \mathrm{~g} \mathrm{WG}$ protein (WG20, WG40 and
Table 1. Composition of diets used in digestibility experiment (Experiment 1)

\begin{tabular}{lccr}
\hline \multirow{2}{*}{ Indices } & \multicolumn{3}{c}{ Experimental diets ${ }^{1}$} \\
\cline { 2 - 4 } & WG20 & WG40 & WG60 \\
\hline Ingredients, $\mathrm{g} \cdot \mathrm{kg}^{-1}$ & & & \\
wheat & 550.00 & 550.00 & 550.00 \\
maize & 150.00 & 150.00 & 150.00 \\
soyabean meal & 80.00 & 80.00 & 80.00 \\
full fat soyabeans & 50.00 & 50.00 & 50.00 \\
casein & 10.00 & 10.00 & 10.00 \\
wheat gluten & 26.72 & 52.86 & 79.00 \\
rapeseed oil & 21.00 & 18.00 & 16.00 \\
calcium phosphate & 16.00 & 16.00 & 16.00 \\
limestone & 12.00 & 12.00 & 12.00 \\
salt & 3.50 & 3.50 & 3.50 \\
vitamin-mineral mixture & 5.00 & 5.00 & 5.00 \\
chromium oxide & 3.00 & 3.00 & 3.00 \\
maize starch & 68.10 & 45.70 & 22.10 \\
L-lysine HCl (78\%) & 4.29 & 3.86 & 3.43 \\
DL-methionine (98\%) & 0.35 & 0.03 & 0.00 \\
Content of crude protein and total amino acids, g $\mathrm{kg}^{-1}$ & \\
crude protein & 169 & 193 & 213 \\
lysine & 7.87 & 8.65 & 9.46 \\
threonine & 4.30 & 5.33 & 6.13 \\
methionine & 2.20 & 2.59 & 3.08 \\
cysteine & 3.31 & 3.81 & 4.46 \\
tryptophan & 1.88 & 2.06 & 2.25 \\
isoleucine & 5.35 & 6.87 & 8.54 \\
arginine & 6.69 & 8.23 & 9.72 \\
histidine & 3.18 & 4.06 & 4.65 \\
leucine & 9.86 & 13.20 & 15.72 \\
phenylanine & 6.48 & 8.28 & 9.84 \\
valine & 6.19 & 7.52 & 9.13 \\
treonine:lysine & 0.55 & 0.62 & 0.65 \\
\hline
\end{tabular}

${ }^{1}$ WG20, WG40, WG60 - diets containing 20.4, 40.4, $60.4 \mathrm{~g}$ wheat gluten protein per $\mathrm{kg}$, respectively; ${ }^{2}$ provided per kg diet: IU: vit. A 15000 , vit. $D_{3} 2000$; mg: vit. $E 60$, vit. $B_{1} 1$, vit. $B_{2} 4$, biotin 0.25 , vit. $B_{6} 3$, vit. $B_{12} 0.02$, vit. $K 3$, niacin 20 , folic acid 5 , Ca pantothenian 15 , choline 150, Mg 150, Mn 50, Zn 150, Se 0.3, Cu 150, Fe 125; g: Ca 1.3

WG60, respectively) were prepared. Wheat gluten was used because it is rich in NEAA (about $60 \%$ in wheat gluten protein) and low in Thr. All diets were formulated from the same ingredients and contained chromium oxide as a marker. The composition of the diets is given in Table 1. All diets were free of antibiotics and other promoters.

In Experiment 2, the composition of the lowThr diets differing in WG contents was the same as the diets evaluated in Experiment 1 except that they were supplemented with essential AAs (excluding Thr) to cover pig requirements according to the ideal protein profile (Boisen, 1997) using the SID values obtained in Experiment 1. The composition of the diets, amounts of supplementary AAs, and content of NEAA in the diets are given in Table 2. The low Thr diets containing $5.1 \mathrm{~g}$ of SID Thr and WG20, WG40 or WG60 as the source of NEAA, 
Table 2. Composition of diets containing the lowest amount of threonine used in balance experiment (Experiment 2)

\begin{tabular}{|c|c|c|c|}
\hline \multirow{2}{*}{ Indices } & \multicolumn{3}{|c|}{ Experimental diets ${ }^{1}$} \\
\hline & WG20 & WG40 & WG60 \\
\hline \multicolumn{4}{|l|}{ Ingredients, $\mathrm{g} \cdot \mathrm{kg}^{-1}$} \\
\hline basic ingredients (sum) & 876.50 & 876.50 & 876.50 \\
\hline wheat gluten & 26.72 & 52.86 & 79.00 \\
\hline rapeseed oil & 21.00 & 18.00 & 16.00 \\
\hline maize starch & 62.16 & 43.96 & 22.79 \\
\hline L-lysine $\mathrm{HCl}(78 \%)$ & 8.17 & 7.04 & 5.71 \\
\hline L-threonine $(98 \%)^{3}$ & 1.55 & 0.69 & \\
\hline DL-methionine (98\%) & 1.18 & 0.53 & \\
\hline L-tryptophan (99\%) & 0.37 & 0.18 & \\
\hline L-isoleucine (99\%) & 0.75 & & \\
\hline L-valine $(96.5 \%)$ & 1.38 & 0.24 & \\
\hline L-histidine (99\%) & 0.22 & & \\
\hline \multicolumn{4}{|c|}{ Content of total non-essential amino acids, $\mathrm{g} \cdot \mathrm{kg}^{-1}$} \\
\hline alanine & 5.34 & 6.37 & 7.48 \\
\hline aspartic acid & 11.12 & 12.85 & 15.03 \\
\hline glutamic acid & 46.31 & 60.04 & 73.80 \\
\hline glycine & 5.52 & 6.72 & 7.90 \\
\hline proline & 12.53 & 16.74 & 19.24 \\
\hline serine & 6.85 & 8.41 & 10.25 \\
\hline tyrosine & 4.20 & 5.35 & 6.28 \\
\hline sum & 91.87 & 116.48 & 139.98 \\
\hline \multicolumn{4}{|c|}{ Content of standardized ileal digestible protein and amino acids, $\mathrm{g} \cdot \mathrm{kg}^{-1}$} \\
\hline protein & 147 & 167 & 187 \\
\hline lysine & 10.00 & 10.00 & 10.00 \\
\hline threonine & 5.10 & 5.10 & 5.10 \\
\hline methionine & 2.78 & 2.78 & 2.78 \\
\hline tryptophan & 1.78 & 1.78 & 1.78 \\
\hline isoleucine & 5.50 & 6.07 & 7.67 \\
\hline valine & 6.81 & 6.80 & 8.09 \\
\hline histidine & 3.00 & 3.58 & 4.12 \\
\hline arginine & 6.11 & 7.47 & 8.93 \\
\hline leucine & 8.66 & 11.72 & 14.05 \\
\hline threonine:lysine & 0.51 & 0.51 & 0.51 \\
\hline \multicolumn{4}{|c|}{ Content of metabolizable energy, $\mathrm{MJ} \cdot \mathrm{kg}^{-1}$} \\
\hline calculated $^{4}$ & 14.0 & 14.0 & 14.0 \\
\hline analysed ${ }^{5}$ & 14.4 & 14.5 & 14.5 \\
\hline
\end{tabular}

${ }^{1}$ see Table $1 ;{ }^{2}$ wheat, maize, soyabean meal, full-fat soyabeans, casein, dicalcium phosphate, limestone, salt, vitamin-mineral mixture as given in Table $1 ;{ }^{3}$ diets containing the lowest threonine content ( $5.1 \mathrm{~g}$ standardized ileal digestible threonine per $\mathrm{kg}$ ) were additionally supplemented with $0.61,1.22$ and $1.83 \mathrm{~g} \mathrm{L-threonine} \mathrm{to} \mathrm{obtain} \mathrm{diets}$ containing 5.7, 6.3 and $6.9 \mathrm{~g}$ standardized ileal digestible threonine per kg; L-threonine were included to diets instead of maize starch; ${ }^{4}$ calculated as a sum of metabolizable energy of dietary compounds; ${ }^{5}$ analysed in balance experiment

were additionally supplemented with $0.61,1.22$ and $1.83 \mathrm{~g} \mathrm{~L}-\mathrm{Thr} \cdot \mathrm{kg}^{-1}$. The four dietary levels of SID Thr were: $5.1,5.7,6.3$, and $6.9 \mathrm{~g} \cdot \mathrm{kg}^{-1}$ corresponding to SID Thr-to-SID lysine ratios of $0.51,0.57,0.63$, and 0.69 , respectively. The diets were prepared from the same batches of feed ingredients as in Experiment 1 and were free of antibiotics and other promoters.

\section{Animals and experimental procedures}

The experiments were performed on male Large White $\times$ Duroc pigs. The animals were housed individually in metabolic cages with a slatted floor in a thermally controlled room $\left(22-23{ }^{\circ} \mathrm{C}\right)$ with free access to water.

Experiment 1 was determined on six pigs with an initial body weight (BW) of about $20 \mathrm{~kg}$ using a cross-over design. The pigs were surgically fitted with a post-valvular T-caecum cannula (PVTC) according to van Leeuwen et al. (1991). The recovery lasting 10 days was followed by 7-day periods of feeding the experimental diets. The feeding level was adjusted to $5 \%$ of BW corresponding to about $90 \%$ of ad libitum intake. The pigs were fed twice a day at 8:00 and 20:00 with equal portions of meal diets mixed with water (1:1). During the last three days of experimental feeding, ileal digesta was collected from 8:00 to 20:00 (between meals). The daily digesta were stored frozen and, after thawing, were pooled per animal within each experimental period and freeze-dried for analysis.

Experiment 2 was performed on 72 pigs divided into twelve groups (six pigs each), taking BW, age and litter into account. Pigs of mean initial BW 12.5 $\mathrm{kg}$ were fed on experimental diets for 20 days. After seven days of adaptation, the pigs were fed a starter diet with daily incremental addition of the test diets. Equal portions were given at 8:00, 14:00 and 20:00, after mixing with water $(1: 1)$. At a mean BW of approximately $19 \mathrm{~kg}, \mathrm{~N}$ balance and metabolizable energy of diets were determined during a 14-day period. The daily dietary allowance was provided at the rate of about $5 \%$ of BW and kept constant during the last nine days of the $\mathrm{N}$ balance period. Faeces and urine were collected during six days. Faeces were collected five times daily and stored at $-20{ }^{\circ} \mathrm{C}$. At the end of each collection period, the faeces were thawed, mixed and subsampled for subsequent analysis. Urine was collected continuously over the period in a plastic container to which $\mathrm{H}_{2} \mathrm{SO}_{4}$ was added daily. Urine volume was measured and recorded daily and a $10 \%$ aliquot was stored at $4{ }^{\circ} \mathrm{C}$ until analysis.

After slaughter at about $22.4 \mathrm{~kg} \mathrm{BW}$, the liver and pancreas were weighed. Tissue samples were taken and stored at $-80{ }^{\circ} \mathrm{C}$ until determination of TDG activity.

\section{Chemical analyses}

Dry matter (code no. 934.01) in dietary ingredients and diets, $\mathrm{N}$ (code no. 954.01) in ingredients, diets, digesta, faeces and urine, were analysed using standard methods (AOAC, 2011). Chromic oxide was determined according to Kimura and Miller 
(1957). Amino acid analyses were performed with a Beckman high pressure System Gold AA analyzer (Beckman Instruments, Inc., Fullerton, CA, USA) using modified procedures according to Buraczewska and Buraczewski (1984). The gross energy of diets and faeces was determined by a Parr adiabatic oxygen bomb KL-10 calorimeter (Precyzja, Bydgoszcz, Poland).

Threonine dehydrogenase activity was measured as the rate of aminoacetone formation according to the method described by Simpson (1998).

\section{Calculations and statistical analysis}

Calculation of AA ileal digestibility was based on the chromium oxide content in diets and digesta. The apparent ileal digestibility of AAs was calculated using the equation given by Buraczewska et al. (1999). The standardized ileal digestibility of AAs was estimated from apparent ileal digestibility of AAs using values of endogenous AAs losses according to Jansman et al. (2002).

Total digestibility of energy was calculated as the difference between the gross energy content in diet and faeces. Metabolizable energy values of diets were calculated from digestible energy values using the Equation no. 43 given by Noblet and Perez (1993). Metabolizable energy values of diets were also calculated as a sum of the metabolizable energy values of dietary components.

Nitrogen retention was calculated as the difference between $\mathrm{N}$ intake and $\mathrm{N}$ output in faeces and urine and expressed in grams $\mathrm{N}$ per day.

The results were expressed as the mean of six pigs. Data were statistically evaluated using Statistica 10 PL (StatSoft Inc., 2011). The results of Experiment 1 were subjected to one-way ANOVA, while the results of Experiment 2, to two-way ANOVA. Additionally, the results of Experiment 2 were subjected to oneway ANOVA for each SID Thr level separately. Differences among groups in both experiments were evaluated using the Tukey post-hoc test.

\section{Results}

\section{Composition of diets}

Supplementation of the WG40 and WG60 diets with 40 and $60 \mathrm{~g} \mathrm{WG}$ protein increased the crude protein content from $17 \%$ to $19 \%$ and $21 \%$ (Table 1), and increased the total content of NEAA by $26 \%$ and $25 \%$ of their content in the WG20 diet, respectively (Table 2). The main component of NEAA was glutamic acid. The analysed metabolizable energy content of the diets did not differ (Table 2).
Table 3. Standardized ileal digestibility of protein and amino acid in diets used in digestibility experiment (Experiment 1)

\begin{tabular}{|c|c|c|c|c|c|}
\hline \multirow{2}{*}{ Indices } & \multicolumn{3}{|c|}{ Experimental diets ${ }^{1}$} & \multirow{2}{*}{$\begin{array}{l}\text { Pooled } \\
\text { SEM }\end{array}$} & \multirow{2}{*}{$P$} \\
\hline & WG20 & WG40 & WG60 & & \\
\hline Protein & 87.2 & 86.6 & 87.9 & 0.6 & 0.323 \\
\hline Lysine & 80.2 & 79.9 & 81.8 & 1.0 & 0.407 \\
\hline Threonine & 83.3 & 83.1 & 83.2 & 1.0 & 0.997 \\
\hline Methionine & 87.6 & 88.3 & 90.2 & 0.6 & 0.061 \\
\hline Cysteine & 86.1 & 85.0 & 86.4 & 0.8 & 0.502 \\
\hline Isoleucine & 89.0 & 88.3 & 89.8 & 0.5 & 0.100 \\
\hline Arginine & 91.4 & 90.8 & 91.9 & 0.3 & 0.054 \\
\hline Histidine & 87.5 & 88.2 & 88.5 & 0.5 & 0.328 \\
\hline Leucine & 87.8 & 88.8 & 89.4 & 0.4 & 0.074 \\
\hline Phenylalanine & 90.1 & 90.1 & 90.9 & 0.4 & 0.316 \\
\hline Valine & 88.5 & 87.4 & 88.6 & 0.5 & 0.297 \\
\hline
\end{tabular}

${ }^{1}$ see Table 1

\section{Amino acid ileal digestibility (Experiment 1)}

Protein and AAs ileal digestibility (SID) of the Thr-deficient diets differing in WG content are gi-ven in Table 3. The wheat gluten level in the diets had no effect on the SID of CP and AAs. The differences were small for $\mathrm{Thr}(83.1 \%-83.3 \%)$, greater for lysine $(79.9 \%-81.8 \%)$, and the greatest for methionine $(87.6 \%-90.2 \%)$. The actual digestibility coefficients were used in formulation of diets containing adequate levels of essential AAs and graded content of Thr ranging from 5.1 to $6.9 \mathrm{~g}$ SID $\mathrm{Thr} \cdot \mathrm{kg}^{-1}$ diet, used in Experiment 2 (Table 2).

\section{Nitrogen retention (Experiment 2)}

The $\mathrm{N}$ balance results are presented in Table 4 . The differences in daily $\mathrm{N}$ intake were due to the increase of the dietary CP content from $17 \%$ to $19 \%$ and $21 \%$ in the WG20, WG40 and WG60 diets, respectively.

Faecal $\mathrm{N}$ excretion was not affected by either the SID Thr or WG levels. The dietary SID Thr level did not significantly influence urinary and total $\mathrm{N}$ excretion, and consequently, had no effect on $\mathrm{N}$ retention. In contrast, all of these parameters were significantly affected $(P \leq 0.001)$ by $\mathrm{WG}$, and were the smallest in pigs fed the WG20 diet and the highest in pigs fed WG60. Total $\mathrm{N}$ excretion was increased significantly by each level of WG and at each level of SID Thr, whereas $\mathrm{N}$ retention was increased to similar values by feeding the WG40 and WG60 diets, the effect of WG being significant only in pigs fed the diets with the lowest $\left(5.1 \mathrm{~g}^{-\mathrm{kg}^{-1}}\right)$ and moderate $\left(6.3 \mathrm{~g} \cdot \mathrm{kg}^{-1}\right)$ SID Thr amounts. Neither parameter was affected by interaction of SID Thr and WG levels. 
Table 4. Nitrogen balance of pigs fed diets differing in standardized ileal digestible threonine content and wheat gluten level (Experiment 2)

\begin{tabular}{|c|c|c|c|c|c|c|}
\hline $\begin{array}{l}\text { Standardized ileal } \\
\text { digestible threonine } \\
\mathrm{g} \cdot \mathrm{kg}^{-1}\end{array}$ & $\begin{array}{l}\text { Wheat gluten } \\
\text { level }^{1}\end{array}$ & $\begin{array}{l}\mathrm{N} \text { intake }^{2} \\
\mathrm{~g} \cdot \text { day }^{-1}\end{array}$ & $\begin{array}{l}\text { Urinary } \\
N \text { excretion } \\
\mathrm{g} \cdot \text { day }^{-1}\end{array}$ & $\begin{array}{l}\text { Faecal } \\
N \text { excretion } \\
\mathrm{g} \cdot \text { day }^{-1}\end{array}$ & $\begin{array}{l}\text { Total } \\
\text { N excretion } \\
\mathrm{g} \cdot \text { day }^{-1}\end{array}$ & $\begin{array}{l}\mathrm{N} \text { retention } \\
\mathrm{g} \cdot \text { day }^{-1}\end{array}$ \\
\hline 5.1 & 20 & 23.0 & $4.5^{\mathrm{a}}$ & 3.4 & $7.8^{\mathrm{a}}$ & $15.1^{\mathrm{a}}$ \\
\hline 5.1 & 40 & 26.0 & $6.7^{\mathrm{b}}$ & 3.2 & $9.9^{b}$ & $16.1^{\mathrm{ab}}$ \\
\hline 5.1 & 60 & 29.0 & $8.9^{c}$ & 3.4 & $12.4^{c}$ & $16.6^{b}$ \\
\hline \multicolumn{3}{|c|}{$P$-value (one-way ANOVA) ${ }^{3}$} & 0.001 & 0.461 & 0.001 & 0.004 \\
\hline 5.7 & 20 & 23.0 & $3.9^{\mathrm{a}}$ & 3.2 & $7.2^{\mathrm{a}}$ & 15.7 \\
\hline 5.7 & 40 & 26.0 & $6.3^{b}$ & 3.3 & $9.6^{b}$ & 16.4 \\
\hline 5.7 & 60 & 29.0 & $9.1^{\mathrm{c}}$ & 3.5 & $12.6^{c}$ & 16.4 \\
\hline \multicolumn{3}{|c|}{$P$-value (one-way ANOVA) } & 0.001 & 0.569 & 0.001 & 0.084 \\
\hline 6.3 & 20 & 23.0 & $4.2^{\mathrm{a}}$ & 3.3 & $7.5^{\mathrm{a}}$ & $15.3^{a}$ \\
\hline 6.3 & 40 & 26.0 & $6.3^{b}$ & 3.3 & $9.7^{\mathrm{b}}$ & $16.4^{\mathrm{ab}}$ \\
\hline 6.3 & 60 & 29.0 & $9.7^{c}$ & 3.2 & $12.9^{c}$ & $16.1^{b}$ \\
\hline \multicolumn{3}{|c|}{$P$-value (one-way ANOVA) } & 0.001 & 0.913 & 0.001 & 0.019 \\
\hline 6.9 & 20 & 23.0 & $4.6^{\mathrm{a}}$ & 3.4 & $7.9^{a}$ & 15.0 \\
\hline 6.9 & 40 & 26.0 & $7.2^{\mathrm{b}}$ & 3.3 & $10.5^{b}$ & 15.6 \\
\hline 6.9 & 60 & 29.0 & $9.2^{c}$ & 3.5 & $12.7^{\circ}$ & 16.3 \\
\hline \multicolumn{3}{|c|}{$P$-value (one-way ANOVA) } & 0.001 & 0.594 & 0.001 & 0.181 \\
\hline \multicolumn{3}{|l|}{ Pooled SEM } & 0.3 & 0.2 & 0.5 & 0.2 \\
\hline \multicolumn{7}{|c|}{ Standardized ileal digestible threonine, $\mathrm{g} \mathrm{kg}^{-1}$} \\
\hline \multicolumn{2}{|c|}{5.1} & 26.0 & 6.7 & 3.4 & 10.1 & 16.0 \\
\hline \multicolumn{2}{|l|}{5.7} & 26.1 & 6.6 & 3.3 & 9.9 & 16.3 \\
\hline \multicolumn{2}{|l|}{6.3} & 26.1 & 6.9 & 3.3 & 10.2 & 16.0 \\
\hline \multicolumn{2}{|l|}{6.9} & 26.0 & 7.0 & 3.4 & 10.4 & 15.7 \\
\hline \multicolumn{7}{|l|}{ Wheat gluten level } \\
\hline \multicolumn{2}{|l|}{20} & 23.0 & $4.4^{\mathrm{a}}$ & 3.3 & $7.7^{\mathrm{a}}$ & $15.3^{\mathrm{a}}$ \\
\hline \multicolumn{2}{|l|}{40} & 26.0 & $6.6^{\mathrm{b}}$ & 3.3 & $9.9^{b}$ & $16.2^{b}$ \\
\hline \multicolumn{2}{|l|}{60} & 29.0 & $9.1^{c}$ & 3.4 & $12.7^{c}$ & $16.3^{b}$ \\
\hline \multicolumn{7}{|c|}{$P$-value (two-way ANOVA) } \\
\hline \multicolumn{3}{|c|}{ standardized ileal digestible threonine } & 0.484 & 0.837 & 0.397 & 0.158 \\
\hline \multicolumn{3}{|l|}{ wheat gluten level } & 0.001 & 0.485 & 0.001 & 0.001 \\
\hline \multicolumn{3}{|l|}{ interaction } & 0.404 & 0.897 & 0.750 & 0.638 \\
\hline
\end{tabular}

${ }^{1}$ see Table $1 ;{ }^{2}$ pigs within a group had the same $\mathrm{N}$ intake; ${ }^{3}$ effect of wheat gluten was calculated for each standardized ileal digestible threonine level separately; abc means with different superscipts within column are significantly different at $P \leq 0.05$

\section{Threonine dehydrogenase activity in the liver and pancreas (Experiment 2)}

The relative tissue weight and TDG activity are presented in Table 5. The liver weight was similar in all animals. The pancreas weight was not affected by SID Thr, but was significantly greater in pigs fed the WG40 diet as compared with the WG20 diet $(P \leq 0.05)$.

Enzyme activity was higher in the pancreas $\left(0.19-0.63 \mu \mathrm{mol} \cdot 15 \mathrm{~min} \cdot \mathrm{g}^{-1}\right)$ than in the liver $\left(0.15-0.35 \mu \mathrm{mol} \cdot 15 \mathrm{~min} \cdot \mathrm{g}^{-1}\right)$. The TDG activity in the liver was not affected by dietary SID Thr, but in the pancreas, significantly greater TDG activity was found in pigs fed diets containing 5.7-6.9 $\mathrm{g}$
SID Thr $\cdot \mathrm{kg}^{-1}$ than with the lowest SID Thr content $(P \leq 0.001)$.

The dietary level of WG affected TDG activity in both tissues. In the liver, TDG activity was significantly greater in pigs fed diet WG60 in comparison with diets WG20 and WG40 $(P \leq 0.001)$ and this effect was found across all SID Thr levels. In contrast, TDG activity in the pancreas was significantly greater in pigs fed WG20 diet in comparison with pigs fed WG40 diet, but not WG60 $(P \leq 0.01)$. The effect of WG on TDG activity in the pancreas was significant only in pigs fed diets containing 5.1 and $6.3 \mathrm{~g}$ SID Thr per $\mathrm{kg}$ diet, but interaction between the effects of the two factors was not found. 
Table 5. Tissue weight and threonine dehydrogenase (TDG) activity in the liver and pancreas of pigs fed diets differing in standardized ileal digestible threonine content and wheat gluten level (Experiment 2)

\begin{tabular}{|c|c|c|c|c|c|}
\hline \multirow{2}{*}{$\begin{array}{l}\text { Standardized ileal } \\
\text { digestible threonine } \\
\mathrm{g} \cdot \mathrm{kg}^{-1}\end{array}$} & \multirow[b]{2}{*}{$\begin{array}{l}\text { Wheat gluten } \\
\text { level }^{1}\end{array}$} & \multicolumn{2}{|l|}{ Liver } & \multicolumn{2}{|l|}{ Pancreas } \\
\hline & & $\begin{array}{l}\text { weight } \\
\mathrm{g} \cdot \mathrm{kg}^{-1} \mathrm{BW}\end{array}$ & $\begin{array}{l}\text { TDG activity } \\
\mu \mathrm{mol} \cdot 15 \mathrm{~min} \cdot \mathrm{g}^{-1}\end{array}$ & $\begin{array}{l}\text { weight } \\
\mathrm{g} \cdot \mathrm{kg}^{-1} \mathrm{BW}\end{array}$ & $\begin{array}{l}\text { TDG activity } \\
\mu \mathrm{mol} \cdot 15 \mathrm{~min} \cdot \mathrm{g}^{-1}\end{array}$ \\
\hline 5.1 & 20 & 22.3 & $0.16^{a}$ & 1.6 & $0.33^{\mathrm{ab}}$ \\
\hline 5.1 & 40 & 21.3 & $0.16^{\mathrm{a}}$ & 2.2 & $0.19^{a}$ \\
\hline 5.1 & 60 & 20.6 & $0.34^{b}$ & 1.8 & $0.39^{b}$ \\
\hline \multicolumn{2}{|c|}{$P$-value (one-way ANOVA) ${ }^{2}$} & 0.608 & 0.007 & 0.076 & 0.026 \\
\hline 5.7 & 20 & 20.6 & $0.17^{\mathrm{a}}$ & 1.7 & 0.50 \\
\hline 5.7 & 40 & 20.5 & $0.18^{\mathrm{a}}$ & 2.0 & 0.37 \\
\hline 5.7 & 60 & 19.6 & $0.35^{b}$ & 1.9 & 0.48 \\
\hline \multicolumn{2}{|c|}{$P$-value (one-way ANOVA) } & 0.593 & 0.018 & 0.102 & 0.322 \\
\hline 6.3 & 20 & 21.5 & $0.14^{\mathrm{a}}$ & 1.8 & $0.63^{b}$ \\
\hline 6.3 & 40 & 21.7 & $0.20^{\mathrm{a}}$ & 1.8 & $0.36^{\mathrm{a}}$ \\
\hline 6.3 & 60 & 21.0 & $0.35^{b}$ & 2.0 & $0.45^{\mathrm{ab}}$ \\
\hline \multicolumn{2}{|c|}{$P$-value (one-way ANOVA) } & 0.756 & 0.002 & 0.159 & 0.022 \\
\hline 6.9 & 20 & 20.9 & $0.15^{\mathrm{a}}$ & 1.8 & 0.54 \\
\hline 6.9 & 40 & 22.4 & $0.24^{\mathrm{ab}}$ & 2.1 & 0.45 \\
\hline 6.9 & 60 & 21.1 & $0.37^{b}$ & 1.9 & 0.46 \\
\hline \multicolumn{2}{|c|}{$P$-value (one-way ANOVA) } & 0.802 & 0.001 & 0.486 & 0.784 \\
\hline \multicolumn{2}{|l|}{ Pooled SEM } & 0.8 & 0.09 & 0.1 & 0.11 \\
\hline \multicolumn{6}{|c|}{ Standardized ileal digestible threonine, $\mathrm{g} \mathrm{kg}^{-1}$} \\
\hline \multicolumn{2}{|c|}{5.1} & 21.4 & 0.22 & 1.9 & $0.30^{\mathrm{a}}$ \\
\hline \multicolumn{2}{|l|}{5.7} & 20.2 & 0.24 & 1.9 & $0.45^{\mathrm{b}}$ \\
\hline \multicolumn{2}{|l|}{6.3} & 21.4 & 0.24 & 1.9 & $0.48^{b}$ \\
\hline \multicolumn{2}{|l|}{6.9} & 21.4 & 0.25 & 1.9 & $0.48^{\mathrm{b}}$ \\
\hline \multicolumn{6}{|l|}{ Wheat gluten level } \\
\hline \multicolumn{2}{|l|}{20} & 21.4 & $0.15^{\mathrm{a}}$ & $1.7^{\mathrm{a}}$ & $0.49^{b}$ \\
\hline \multicolumn{2}{|l|}{40} & 21.5 & $0.19^{a}$ & $2.0^{b}$ & $0.33^{a}$ \\
\hline \multicolumn{2}{|l|}{60} & 20.6 & $0.35^{b}$ & $1.9^{\mathrm{ab}}$ & $0.44^{\mathrm{ab}}$ \\
\hline \multicolumn{6}{|c|}{$P$-value (two-way ANOVA) } \\
\hline \multicolumn{2}{|c|}{ standardized ileal digestible threonine } & 0.207 & 0.716 & 0.849 & 0.001 \\
\hline \multicolumn{2}{|c|}{ wheat gluten level } & 0.234 & 0.001 & 0.019 & 0.01 \\
\hline \multicolumn{2}{|l|}{ interaction } & 0.790 & 0.928 & 0.247 & 0.505 \\
\hline
\end{tabular}

${ }^{1}$ see Table $1 ;{ }^{2}$ see Table 4; ${ }^{\text {ab }}$ means with different superscipts within column are significantly different at $P \leq 0.05$

\section{Discussion}

The effects of graded levels of dietary standardized ileal digestible threonine and wheat gluten protein on nitrogen retention. Nitrogen retention in growing pigs is strictly related to body protein deposition and is a reliable indicator of AA adequacy in the diet. In the present study, $\mathrm{N}$ retention was measured to check the optimal level of dietary SID Thr and to verify the hypothesis on the sparing effect of NEAA added in the form of WG on Thr utilization.

In the present experiment, the lowest SID $\mathrm{Thr}$ content in the unsupplemented diet $\left(5.1 \mathrm{~g} \cdot \mathrm{kg}^{-1}\right.$ and corresponding a 0.51 SID Thr-to-SID lysine ratio) was smaller, whereas the highest content $\left(6.9 \mathrm{~g} \cdot \mathrm{kg}^{-1}\right.$ and corresponding to a 0.69 SID Thr-to-SID lysine ratio) was greater than the values recommended by Boisen (1997). The SID Thr content of $5.1 \mathrm{~g}$ (equivalent of $5.8 \mathrm{~g}$ total $\mathrm{Thr}$ ) was similar to that used by Russel et al. (1986) as optimal for pigs weighing from 17 to $38 \mathrm{~kg}$ and was lower than the $5.7 \mathrm{~g}$ SID Thr per kilogram of diet applied as deficient in our previous study (Święch et al., 2011) for pigs of a similar age. The highest Thr content (6.9 g SID Thr equivalent to $7.6 \mathrm{~g}$ total Thr per $\mathrm{kg}$ ) was higher than advised by NRC (1998), but lower than recommended recently by NRC (2012) for pigs weighing from 11 to $25 \mathrm{~kg}$ and 11 to $20 \mathrm{~kg}$, respectively. It was, therefore, assumed that in the present study diets 
containing the lowest amounts of Thr were Thrdeficient, whereas others were covering or slightly exceeding the $\mathrm{Thr}$ requirement of young pigs.

Contrary to expectations, increasing the SID Thr content over $5.1 \mathrm{~g}$ per kilogram of the diet did not influence $\mathrm{N}$ retention, which indicates that the lowest Thr level covered the requirement of young pigs for deposition of about $100 \mathrm{~g}$ protein daily.

Similar results were reported by Le Floc'h et al. (1996), who observed that $\mathrm{N}$ retention only tended to be higher in growing pigs fed on diets with a 0.79 and 0.91 total Thr-to-total lysine ratio than when it equaled 0.61 . The present results disagree with our previous studies (Święch et al., 2010, 2011) that showed that $\mathrm{N}$ retention was negatively affected by moderate Thr deficiency. The absence of the effect of potential Thr deficiency on $\mathrm{N}$ retention can be partly explained by the relatively high dietary protein content, which ranged from $17 \%$ to $21 \%$. This explanation is supported by the results of Buraczewska et al. (2006), who demonstrated that $\mathrm{N}$ retention was affected by the dietary Thr level only in pigs fed a diet with a low (16\%) protein content, as compared with a higher $(18 \%)$ protein level. However, in our previous study (Święch et al., 2011), N retention was negatively affected by $\mathrm{Thr}$ deficiency also when pigs were fed a diet containing $21 \%$ protein. These apparent discrepancies between approximations of deficient vs adequate Thr levels may indicate that not only lysine, but also protein level should be taken into account when diets with an optimal Thr content are formulated.

Supplementation of both Thr-deficient and Thradequate diets with WG obviously increased $\mathrm{N}$ intake and also urinary $\mathrm{N}$ excretion, but it also increased or tended to increase $\mathrm{N}$ retention. The overall stimulating effect of WG on protein deposition did not depend on the WG level in the diet and was not affected by the dietary Thr content. An interactive effect of dietary SID Thr and WG levels on N retention was not found. However, the significant effect of WG was greater in pigs fed the diet with the lowest, compared with the moderate, Thr content and this result is partly in agreement with the findings in our previous study (Święch et al., 2010). In that experiment, the NEAA (in the form of wheat gluten and monosodium glutamate) added to a Thrdeficient diet had a slight positive effect on daily $\mathrm{N}$ retention and promoted similar $\mathrm{N}$ retention values as the Thr-adequate diet. It may, therefore, be assumed that the Thr-sparing effect of NEAA on protein deposition can be expected when Thr deficiency is actually limiting protein metabolism.
Effects of graded levels of standardized ileal digestible threonine and wheat gluten protein on the activity of the enzyme involved in threonine metabolism. The catabolic activity of TDG is supposed to be higher in animals fed a diet with the Thr content exceeding their actual requirement for this AA. In the present experiment, this assumption was confirmed only in the case of TDG activity in the pancreas and only when the activity at the lowest SID Thr level was compared with that at three higher levels. The increase of the dietary SID Thr level over $5.7 \mathrm{~g} \cdot \mathrm{kg}^{-1}$ was not accompanied by further significant increases of TDG activity. The TDG activity in the liver was not affected by the dietary Thr content except for a slight (non-significant) tendency towards lower TDG activity at the lowest Thr level.

The results of the present study are similar to those obtained by Le Floc'h et al. (1995) who found significantly lower TDG activity in the pancreas of pigs fed Thr-deficient than Thr-adequate diets and did not find any effect of Thr level on TDG activity in the liver. Also in another study by Le Floc'h et al. (1996) and by Święch et al. (2010), TDG activities were lower on Thr-deficient than on Thr-adequate diets. Contrary to the present results, these differences were found not only in the pancreas, but also in the liver. However, conflicting results were obtained by Święch et al. (2011), who failed to find any effect of Thr level on TDG activity in either tissue.

Extensive studies by Le Floc'h et al. (1997) and Le Floc'h and Sève (2005) showed that Thr oxidation via the TDG pathway takes place in the liver and pancreas. According to Le Floc'h et al. (1995), relative TDG activity (expressed per gram of tissue or milligram of protein) in the pancreas is equal to or slightly higher than in the liver, but total activity in the pancreas represents only $4 \%-10 \%$ of the activity in the liver. In the present study, the differences between relative TDG activity in the pancreas and liver were greater than reported by Le Floc'h et al. (1995) and were greater at the higher than at the lowest Thr levels. Total TDG activity in the pancreas represented $12 \%-17 \%$ of activity in the liver.

The increase in pancreatic TDG activity indicating more intensive oxidation of this AA in pigs fed diets containing 5.7 (and more) vs $5.1 \mathrm{~g}$ of SID Thr is in line with the absence of any improvement of protein deposition due to the Thr supply being increased to above $5.1 \mathrm{~g} \cdot \mathrm{kg}^{-1}$. These results seem to indicate that under the conditions of the present experiment (age and breed of pigs, protein and feeding level), a dietary content of $5.1 \mathrm{~g}$ SID Thr is satisfactory. 
In the present study, addition of WG40 to diets did not affect TDG activity in the liver, whereas WG60 provoked a considerable increase of TDG at all levels of dietary Thr. This result is only partly in agreement with the studies by Le Floc'h et al. (1994), who found that NEAA supplementation (in the form of glutamic acid) increased TDG activity in the liver, but only when added to a Thr-deficient and not to a Thr-adequate diet. The reported improvement of growth performance of pigs due to glutamic acid supplementation of a Thr-deficient diet was ascribed by these authors to a specific sparing effect on $\mathrm{Thr}$, which could improve its utilization for protein deposition. This result is also partly in line with the irregular, but stimulating effect of $\mathrm{WG}$ on $\mathrm{N}$ retention found in the present study. The effects of glutamic acid reported by Le Floc'h et al. (1994) differed from those of protein supplementation since protein provoked an increase of TDG activity only when added to Thr-adequate and not Thr-deficient diets. Also in our previous study (Święch et al., 2010), TDG activity in the liver and pancreas was increased only when a diet with moderate $\mathrm{Thr}$ deficiency was supplemented with a high amount of WG (and essential AAs) and not with monosodium glutamate. Monosodium glutamate decreased, whereas WG only tended to decrease the Thr concentration in plasma.

The response of pancreatic TDG activity to WG was inconsistent, since in all groups of pigs fed diets differing in Thr content, TDG was, or tended to be, lower in pigs fed the WG40 diet than the WG20 and WG60 diets. This inconsistent response is difficult to explain. TDG activity in the pancreas was least affected by the WG level in the groups fed the diet with the greatest Thr content, but neither in the pancreas nor in the liver was the TDG activity influenced by interaction of Thr and WG levels.

The results of the present and reported (Święch et al., 2010) studies indicate that the effects of NEAA on Thr utilization seem to depend on the form and amount of NEAA and on the degree of Thr deficiency and that the response of TDG activity to dietary factors differs between the liver and pancreas.

\section{Conclusions}

Contrary to expectations, the lowest applied dietary level of $5.1 \mathrm{~g}$ standardized ileal digestible threonine per kilogram diet covered the requirement of young pigs for protein deposition. The results do not evidence a sparing effect of non-essential amino acids added in the form of wheat gluten on threonine utilization when the dietary threonine concentration does not limit protein deposition. Responses of threonine dehydrogenase activity to the increase of dietary threonine and wheat gluten differ between the liver and pancreas: activity in the liver being increased only by wheat gluten, whereas in the pancreas, also by the threonine level, but not in a dose-dependent manner. Therefore, threonine dehydrogenase activity cannot be treated as a sensitive indicator of threonine oxidation rate and adequacy of threonine supply.

\section{Acknowledgements}

This work was supported by Polish National Science Centre, Project No. N N311 316736 (20092014).

\section{References}

AOAC, 2011. Association of Official Analytical Chemists. Official Methods of Analysis. 18 ${ }^{\text {th }}$ Edition. Galthersburg, MA

Boisen S., 1997. Ideal protein - and its suitability to characterize protein quality in pig feeds. A review. Acta Agr. Scand. Sect. A -Anim. Sci. 47, 31-38

Buraczewska L., Buraczewski S., 1984. A note on determination of methionine and tryptophan. In: Proceeding of the $6^{\text {th }}$ International Symposium on Amino Acids. Warsaw (Poland), pp. 47-50

Buraczewska L., Święch E., Le Bellego L., 2006. Nitrogen retention and growth performance of 25 to $50 \mathrm{~kg}$ pigs fed diets of two protein levels and different ratios of digestible threonine to lysine. J. Anim. Feed Sci. 15, 25-36

Buraczewska L., Wasilewko J., Fandrejewski H., Żebrowska T., Han I.K., 1999. Formulation of pig diets according to ileal digestible amino acid content. Livest. Prod. Sci. 59, 13-24

GfE, Gasellschaft für Ernährungsphysiologie, 2006. Recommendations for the Supply of Energy and Nutrients for Pigs. Committee for Requirement Standards of the Society of Nutrition Physiology. DLG-Verlag, Frankfurt am Main (Germany)

Jansman A.J.M., Smink W., van Leeuwen P., Rademacher M., 2002. Evaluation through literature data of the amount and amino acid composition of basal endogenous crude protein at the terminal ileum of pigs. Anim. Feed Sci. Tech. 98, 49-60

Kimura F.T., Miller V.L., 1957. Chromic oxide measurement.. Improved determination of chromic oxide in cow feed and feces. J. Agr. Food Chem. 5, 216, doi: 10.1021/jf60073a008

Le Floc'h N., Obled C., Sève B., 1995. In vivo threonine oxidation rate is dependent on threonine dietary supply in growing pigs fed low to adequate levels. J. Nutr. 125, 2550-2562

Le Floc'h N., Obled C., Sève B., 1996. In vivo threonine oxidation in growing pigs on diets with graded levels of threonine. Brit. J. Nutr. 75, 825-837

Le Floc'h N., Sève B., 2005. Catabolism through the threonine dehydrogenase pathway does not account for the high first-pass extraction rate dietary threonine by the portal drained viscera in pigs. Brit. J. Nutr. 93, 447-456

Le Floc'h` N., Sève B., Henry Y., 1994. The addition of glutamic acid or protein to a threonine-deficient diet differentially affects growth performance and threonine dehydrogenase activity in fattening pigs. J. Nutr. 124, 1987-1995 
Le Floc'h N., Thibault J.-N., Sève B., 1997. Tissue localization of threonine oxidation in pigs. Brit. J. Nutr. 77, 593-603

Noblet J., Perez J.M., 1993. Prediction of digestibility of nutrients and energy values of pig diets from chemical analysis. J. Anim. Sci. 71, 3389-3398

NRC, 1998. Nutrient Requirements of Swine. $10^{\text {th }}$ Edition. National Academy Press. Washington, DC

NRC, 2012. Nutrient Requirements of Swine. $11^{\text {th }}$ Edition. National Academy Press. Washington, DC

Russell L.E., Easter R.A., Gomez-Rojas V., Cromwell G.L., Stahly T.S. 1986. A note on the supplementation of low-protein, maizesoya-bean meal diets with lysine,tryptophan, threonine, and methionine for growing pigs. Anim. Prod. 42, 291-295

Saldana C.I., Knabe D.A., Owen K.Q., Burgoon K.G., Gregg E.J., 1994. Digestible threonine requirements of starter and finisher pigs. J. Anim. Sci. 72, 144-150

Simpson G.J., 1998. Development of methods to improve the estimation of threonine catabolism in the growing pigs. MSc. Thesis, University of Guelph (Canada)
StatSoft, Inc., 2011. STATISTICA (data analysis software system) version 10. www.statsoft.com

Święch E., Boryczka M., Taciak M., Buraczewska L., 2011. The effect of graded levels of dietary threonine on nitrogen retention and structure of the small intestine in young pigs. J. Anim. Feed Sci. 20, 350-360

Święch E., Buraczewska L., Tuśnio A., Taciak M., 2010. The effects of supplementing a low-protein threonine-deficient diets with different sources of non-essential amino acids on nitrogen retention and gut structure in young pigs. Arch. Anim. Nutr. 64, 22-35

van Leeuwen P., van Kleef D.J., van Kempen G.J.M., Huisman J., Verstegen M.W.A., 1991. The Post Valve T-Ceacum cannulation technique in pigs applicated to determine the digestibility of amino acids in maize, groundnut and sunflower meal. $\mathrm{J}$. Anim. Physiol. Anim. Nutr. 65, 183-193

Wang X., Qiao S., Yin Y., Yue L., Wang Z., Wu G., 2007. A deficiency or excess of dietary threonine reduces protein synthesis in jejunum and skeletal muscle of young pigs. J. Nutr. 137, 1442-1446 